\title{
Effect of Calcium Chloride Addition on Ice Cream Structure and Quality
}

\author{
F. F. Costa, ${ }^{\star} \dagger$ J. V. Resende, $†$ L. R. Abreu, $\dagger$ and H. D. Goff*1 \\ *Department of Food Science, University of Guelph, Guelph, Ontario, Canada, N1G 2W1 \\ †Federal University of Lavras, CEP 37200-000, Lavras, Minas Gerais, Brazil
}

\begin{abstract}
The influence of calcium fortification by the addition of calcium chloride on quality parameters of ice cream based on physical properties was investigated, as was the effect of $\kappa$-carrageenan at modifying the effects of this calcium fortification. Four ice cream mixes of conventional composition, with added $\kappa$-carrageenan ( 0 or $0.025 \%)$ and added calcium chloride (0 or $4.4 \mathrm{~g} \mathrm{~L}^{-1}=$ $40 \mathrm{~m} M$ of added $\mathrm{Ca}^{2+}$ ), were prepared. Modulated temperature-differential scanning calorimetry was used to investigate the effect of calcium chloride on the nucleation temperature, enthalpy of melting, and freezing point depression. The protein composition of $15.4 \%$ (wt/ wt) reconstituted skim milk powder solutions with or without $4.4 \mathrm{~g} \mathrm{~L}^{-1}$ added $\mathrm{CaCl}_{2}$ and in the supernatant after ultracentrifugation was determined. Fat particle size distributions in ice cream were characterized by light scattering. Ice crystal sizes before and after temperature cycling were determined by cold-stage light microscopy. The results demonstrated that the addition of calcium chloride led to a substantial increase in ice crystal sizes and in fat partial coalescence, which were exacerbated by the addition of $\kappa$-carrageenan. These results can be explained by the interaction between $\mathrm{Ca}^{2+}$ ions and casein micelles, rather than any effects on freezing point depression. The calcium ions led to a more compact micelle, less serum $\beta$-casein, and high fat destabilization, all of which would be expected to reduce macromolecular structure and volume occupancy in the unfrozen phase, which led to increased rates of ice recrystallization.
\end{abstract}

Key words: calcium fortification, ice cream, ice crystal, fat destabilization

\section{INTRODUCTION}

Food manufacturers add vitamins and minerals to food products to attract the attention of health-conscious consumers (Weaver, 1998) and to respond to pub-

Received December 18, 2007.

Accepted February 15, 2008.

${ }^{1}$ Corresponding author: dgoff@uoguelph.ca lic health needs. Interest in fortifying foods with calcium is growing due to the difficulty for many individuals to meet calcium requirements with unfortified foods; the large incidence of osteoporosis, especially in elderly women; and the marketing advantage of using a health claim linking calcium to osteoporosis. Calcium is an essential mineral for human health (e.g., bone strength). The daily adequate intake value is between 1,000 and 1,300 mg, depending on sex and age. Most sex-age groups do not meet this adequate intake, based on nutrient intake surveys, and this is especially so in young women, who are at a critical age for the development of bone mass that can alleviate bone mass loss in later years (USDA, 2005). In milk, the calcium content is about $1,200 \mathrm{mg} \mathrm{L}^{-1}$ (Fox and McSweeney, 1998), making it a good source of dietary calcium. The calcium in milk is also highly bioavailable ( $\sim 30 \%)$, compared with that of plant sources, which typically contain phytates capable of binding calcium and reducing intestinal absorption (Weaver and Heaney, 2006). A recent study has also shown that the bioavailability of calcium from ice cream equals that of milk, despite concerns about the effects of higher fat on reduced calcium solubility (Berry, 2007). The natural connection in the mind of consumers between calcium and dairy products also makes them a prime target food category for fortification (Singh et al., 2007), and calcium-fortified dairy products can already be found on the market. In a previous study (Costa, 2006; Costa et al., 2006), the addition of calcium chloride to ice cream had a significant effect on ice cream structure and quality, leading to an increase in ice crystal size. This phenomenon is very important to understand and control, to allow manufacturers to effectively fortify products without compromising quality. Thus, the objectives of this study were to investigate and to understand the effects of calcium chloride addition, as a source of soluble and ionic calcium, and its interaction with $\kappa$-carrageenan on ice cream structure and quality.

Of the calcium in milk, approximately $1 / 3$ is soluble and $2 / 3$ is associated with the casein micelle, either as colloidal calcium phosphate (about $1 / 2$ of the total milk calcium) or as calcium ions bound to phosphoserine residues (about 1/6 of the total calcium). The micellar 
calcium plays a critical role in micelle structure and stability (De Kruif and Holt, 2003; Little and Holt, 2004). Of the soluble calcium, about $10 \%$ of the total milk calcium is ionized, and most remaining calcium occurs as calcium citrate. There are several important equilibria between ionic, soluble, and micellar calcium, and calcium and other minerals can move from phase to phase when conditions such as $\mathrm{pH}$ or ionic strength are changed (Agboola and Dalgleish, 1996; Antipova et al., 2002; Little and Holt, 2004). Redistribution of these salts can also give rise to redistribution of micellar vs. soluble casein proteins (Tsioulpas et al., 2007). There are several sources of calcium that can be used for fortification, and the advantages and disadvantages of these have been discussed thoroughly (Augustin and Williams, 2002). Insoluble salts need to be properly suspended or carried so as not to adversely affect texture, because they can impart a chalky or particulate mouthfeel. Generally, the addition of soluble calcium salts to milk causes an increase in serum calcium ions, an increase in calcium in the colloidal phase, enhanced micellar aggregation, a decrease in $\mathrm{pH}$, and a decrease in heat stability (Vyas and Tong, 2004; Williams et al., 2005; Singh et al., 2007). With calcium addition, changes to ionic strength with subsequent displacement of $\mathrm{H}^{+}$ions also lead to a decrease in $\mathrm{pH}$ (Williams et al., 2005).

Ice cream is a complex food colloid consisting of fat globules, air bubbles, and ice crystals (Goff, 1997). Air bubbles and ice crystals are usually in the range of 20 to $50 \mu \mathrm{m}$ (Caldwell et al., 1992a). The serum phase consists of the unadsorbed casein micelles in suspension in a freeze-concentrated solution of sugar, unadsorbed whey proteins, salts, and high molecular mass polysaccharides. In the mix, the fat droplets are emulsified by adsorbed proteins, including micellar and nonmicellar casein and whey proteins, and by emulsifiers. During freezing, the partially crystalline fat phase at refrigerated temperatures undergoes partial coalescence during the concomitant whipping and freezing process, resulting in a network of agglomerated fat, which partially surrounds the air bubbles and gives rise to a solid-like structure (Goff, 1997). An increase in the size of ice crystals, as occurs during ice recrystallization from temperature abuse (Caldwell et al., 1992b; Flores and Goff, 1999; Regand and Goff, 2002), is directly correlated to an increase in coarse-icy textures (Russell et al., 1999). Stabilizers are a group of ingredients, usually polysaccharides, commonly used in ice cream formulations to reduce ice recrystallization rate (Marshall et al., 2003). $\kappa$-Carrageenan is usually included as a stabilizer in ice cream (Marshall et al., 2003). It is a linear, negatively charged, sulfated galactan polysaccharide with 1 sulfate group per disaccha- ride (Rees et al., 1969). Its specific function is to limit phase separation between polysaccharide stabilizers and milk proteins (Langendorff et al., 2000; Schorsch et al., 2000; Spagnuolo et al., 2005; Vega et al., 2005), and hence, it is usually added at low concentration relative to the primary stabilizer. Because it also interacts with calcium (Rees et al., 1969; Nickerson et al., 2004; Funami et al., 2007), its specific role in calciumfortified products is of particular interest to the objectives of this work.

\section{MATERIALS AND METHODS}

\section{Ice Cream Processing}

The ice cream mix consisted of $10 \%$ fat (from unsalted butter, $80 \%$ fat, Gay Lea Foods, Guelph, Ontario, Canada), $11 \%$ milk solids-not-fat (MSNF; from instant skim milk powder, 97\% solids, Gay Lea Foods), 12\% sucrose (Redpath Sugar, Toronto, Ontario, Canada), 4\% 42DE corn syrup solids (Casco Inc., Toronto, Ontario, Canada), and $0.15 \%$ Polmo (80\% mono- and diglycerides, 20\% polysorbate 80, Danisco Canada Inc., Scarborough, Ontario, Canada). Calcium chloride (Fisher Scientific, Toronto, Ontario, Canada) at 0 or $4.4 \mathrm{~g} \mathrm{~L}^{-1}$ was added (equal to $40 \mathrm{mM} \mathrm{Ca}{ }^{2+}$ or $1,600 \mathrm{mg}$ of $\mathrm{Ca}^{2+} \mathrm{L}^{-1}$ if it was fully dissociated). The calcium concentration added was equal to that found in the unfortified mix based on the MSNF content, therefore effectively doubling its total calcium concentration, but the added calcium concentration is $3 \times$ the amount found in the aqueous phase of the unfortified mix, due to the significant amount of calcium bound into the casein micelle. $\kappa$-Carrageenan (Danisco Canada Inc.) at 0 or $0.025 \%$ was also added. Mixes were pasteurized in batch at $74^{\circ} \mathrm{C}$ for $15 \mathrm{~min}$ and homogenized at 17.5/3.5 MPa (APV Gaulin, Everett, MA). Mixes were whipped and frozen in a batch ice cream freezer (Taylor model 104, Taylor Freezers, Rockton, IL) to a draw temperature of $-5^{\circ} \mathrm{C}$ and were subsequently hardened at $-35^{\circ} \mathrm{C}$. All samples were prepared in triplicate.

\section{Thermal Properties}

A modulated temperature differential scanning calorimeter (Q1000, TA Instruments, New Castle, DE) was used for thermal property evaluation. The $T_{z e r o}$ calibration was performed with sapphire, heat flow calibration was performed with gallium, temperature calibration was performed with gallium and indium, and heat capacity calibration was performed with sapphire. Nitrogen $\left(300 \mathrm{~mL} \mathrm{~min}^{-1}\right)$ was used as a purge gas. A heatonly modulation, amplitude $\pm 0.318^{\circ} \mathrm{C}$, period $60 \mathrm{~s}$, was used in all experiments. Hermetically sealed alod-al pans (TA Instruments) were used, and the sample size 
Table 1. Characteristics of the total heat flow curve of the ice cream mix samples as a function of calcium chloride or $\kappa$-carrageenan addition, or both

\begin{tabular}{lccc}
\hline Treatment & $\begin{array}{c}\text { Peak melting } \\
\text { temperature }\left({ }^{\circ} \mathrm{C}\right)\end{array}$ & $\begin{array}{c}\text { Enthalpy } \\
(\mathrm{J} / \mathrm{g})\end{array}$ & $\begin{array}{c}\text { Nucleation } \\
\text { temperature }\left({ }^{\circ} \mathrm{C}\right)\end{array}$ \\
\hline $0.025 \% \kappa$-carrageenan; $4.4 \mathrm{~g} \mathrm{~L} \mathrm{~L} \mathrm{CaCl}_{2}$ added & $-1.6^{\mathrm{a}}$ & $222.6^{\mathrm{a}}$ & $-15.7^{\mathrm{a}}$ \\
$0.025 \% \kappa$-carrageenan; no added CaCl & $-1.7^{\mathrm{a}}$ & $220.5^{\mathrm{a}}$ & $-15.9^{\mathrm{a}}$ \\
$0 \% \kappa$-carrageenan; $4.4 \mathrm{~g} \mathrm{~L}^{-1} \mathrm{CaCl}_{2}$ added & $-1.7^{\mathrm{a}}$ & $215.5^{\mathrm{a}}$ & $-17.0^{\mathrm{a}}$ \\
$0 \% \kappa$-carrageenan; no added $\mathrm{CaCl}_{2}$ & $-1.8^{\mathrm{a}}$ & $216.4^{\mathrm{a}}$ & $-16.1^{\mathrm{a}}$ \\
\hline
\end{tabular}

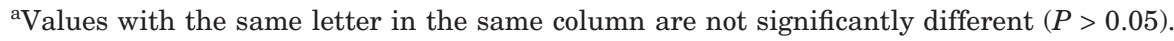

was approximately $20 \mathrm{mg}$. Samples of ice cream mix were equilibrated at $20^{\circ} \mathrm{C}$ and cooled with a temperature rate of $2^{\circ} \mathrm{C} \min ^{-1}$ to $-30^{\circ} \mathrm{C}$, then equilibrated at $-30^{\circ} \mathrm{C}$ for 5 min followed by heating from $-30^{\circ}$ to $15^{\circ} \mathrm{C}$ at $2^{\circ} \mathrm{C} \mathrm{min}^{-1}$.

\section{Ice Recrystallization in Ice Cream}

For temperature cycling, 3 containers of ice cream from each formulation were transferred from $-35^{\circ} \mathrm{C}$ to a cabinet freezer at $-20^{\circ} \mathrm{C}$. Each sample was subjected to a programmed heating and cooling cycle during which the freezer was kept at $-20^{\circ} \mathrm{C}$ for $12 \mathrm{~h}$, then heated to $-10^{\circ} \mathrm{C}$ in $12 \mathrm{~h}$, held for $12 \mathrm{~h}$, and cooled to $-20^{\circ} \mathrm{C}$ in $12 \mathrm{~h}$. This heating-cooling cycle $(48 \mathrm{~h})$ was repeated 10 times on every sample (Regand and Goff, 2006). For image capture and analyses, ice cream, either directly from $-35^{\circ} \mathrm{C}$ storage or after cycling, was tempered at $-20^{\circ} \mathrm{C}$ and then immediately prepared for analyses by light microscopy. All mechanical devices that were used for further treatment were precooled to $-20^{\circ} \mathrm{C}$. Cubes of approximately $1 \mathrm{~cm}^{3}$ were taken from the core section using a sharp knife. A thin slice $(\sim 1$ $\mathrm{mm}^{3}$ ) was subsequently cut with a sharp blade and placed on a drop of iso-amyl-butanol (previously cooled to $-20^{\circ} \mathrm{C}$ ) on a standard glass microscope slide. The slide was covered with a coverslip and placed above liquid nitrogen in an insulated styrofoam container and transported immediately to the cold stage (Linkam Instruments, Surrey, UK), which was previously programmed to a constant temperature of $-17^{\circ} \mathrm{C}$ (Regand and Goff, 2006). Images were acquired using a light microscope (Olympus BH, Tokyo, Japan). Several different fields were photographed from each slide to obtain at least 300 crystals per sample. Measurements of ice crystal size were performed on a Macintosh computer using the public domain NIH Image program Object Image 2.10 by tablet and stylus. Microsoft Excel 2000 was used for further statistical analyses of equivalent circular diameter of the crystals. Ice crystal size distributions were characterized by a logistic dose-response model with a cumulative distribution of equivalent circular diameters (Flores and Goff, 1999). The $\mathrm{X}_{50}$ values were calculated as the theoretical median value of the fitted data to the model (i.e., $50 \%$ of the cumulative distribution of the fitted data).

\section{Protein Distribution}

The protein composition of $15.4 \%$ (wt/wt) skim milk powder solutions (representing the MSNF in water fraction of the mix) and in the supernatant of these solutions, with or without $4.4 \mathrm{~g} \mathrm{~L}^{-1} \mathrm{CaCl}_{2}$ added, after centrifugation at $40,000 \times g$ and $20^{\circ} \mathrm{C}$ for 60 min using a Beckman L8-M ultracentrifuge with a T-47 rotor (Beckman, Fullerton, CA), was determined by capillary electrophoresis (Zhang and Goff, 2004). The buffer (pH 3.0) used to separate proteins consisted of $6.0 \mathrm{M}$ urea, $20 \mathrm{~m} M$ trisodium citrate dihydrate, $0.1 M$ citric acid, and $0.05 \%(\mathrm{wt} / \mathrm{vol})$ hydroxypropylmethyl cellulose. The buffer ( $\mathrm{pH}$ 7.5) used to dissolve the protein sample consisted of 7.0 $M$ urea and $20 \mathrm{~m} M$ bis-tris-propane. Immediately before use, 2 -mercaptoethanol $(5 \mu \mathrm{L}$ per $\mu \mathrm{L}$ of sample buffer) was added to sample buffer. Samples of the protein solutions were diluted 1:4 with the sample buffer and allowed at least $1 \mathrm{~h}$ for protein reduction before sample injection. The $\mathrm{CE}$ was carried out using a Beckman P/ACE System 5510 controlled by Golden Software (Beckman Instruments Inc., San Ramon, CA). The separation of protein on a polyvinyl alcohol-coated

Table 2. Ice crystal median circular equivalent diameter $\left(\mathrm{X}_{50}\right)$ of fresh and temperature-cycled ice cream and percentage of growth for ice cream as a function of added calcium chloride or $\kappa$-carrageenan, or both

\begin{tabular}{lcc}
\hline & \multicolumn{2}{c}{ Ice crystal size $(\mu \mathrm{m})$} \\
\cline { 2 - 3 } Ice cream & $\begin{array}{c}\kappa \text {-Carrageenan } \\
(0.025 \%)\end{array}$ & $\begin{array}{c}\kappa \text {-Carrageenan } \\
(0 \%)\end{array}$ \\
\hline Fresh $\left(4.4 \mathrm{~g} \mathrm{~L}^{-1} \mathrm{CaCl}_{2}\right.$ added) & $64.0^{\mathrm{ab}}$ & $67.2^{\mathrm{a}}$ \\
Fresh (no added $\left.\mathrm{CaCl}_{2}\right)$ & $56.3^{\mathrm{ab}}$ & $54.1^{\mathrm{b}}$ \\
Cycled $\left(4.4 \mathrm{~g} \mathrm{~L}^{-1} \mathrm{CaCl}_{2}\right.$ added) & $89.1^{\mathrm{a}}$ & $81.6^{\mathrm{c}}$ \\
Cycled (no added $\left.\mathrm{CaCl}_{2}\right)$ & $73.9^{\mathrm{b}}$ & $71.7^{\mathrm{bd}}$ \\
Growth \% (4.4 g L $\mathrm{CaCl}_{2}$ added) & $39.2^{\mathrm{a}}$ & $21.5^{\mathrm{c}}$ \\
Growth \% (no added $\left.\mathrm{CaCl}_{2}\right)$ & $31.2^{\mathrm{b}}$ & $32.6^{\mathrm{b}}$ \\
\hline
\end{tabular}

${ }^{\mathrm{a}-\mathrm{d}}$ Values with the same letters within each set of fresh, cycled, or growth $\%$ are not significantly different $(P>0.05)$. 
Table 3. Percentage of supernatant and precipitate after ultracentrifugation of reconstituted skim milk powder solutions as affected by calcium chloride addition

\begin{tabular}{|c|c|c|}
\hline \multirow[b]{2}{*}{ Treatments } & \multicolumn{2}{|c|}{$\begin{array}{c}\text { Skim milk powder } \\
\text { ultracentrifugation }(\% \mathrm{wt} / \mathrm{wt})\end{array}$} \\
\hline & Supernatant & Precipitate \\
\hline $\begin{array}{l}4.4 \mathrm{~g} \mathrm{~L}^{-1} \mathrm{CaCl}_{2} \text { added } \\
\text { No added } \mathrm{CaCl}_{2}\end{array}$ & $\begin{array}{l}82.8^{\mathrm{a}} \\
79.2^{\mathrm{b}}\end{array}$ & $\begin{array}{l}16.2^{\mathrm{a}} \\
19.8^{\mathrm{b}}\end{array}$ \\
\hline
\end{tabular}

${ }^{\mathrm{a}, \mathrm{b}}$ Values with the same letters in the same column are not significantly different $(P>0.05)$.

capillary column (eCAP N-CHO, cat. no. 477601, Beckman-Coulter, San Ramon, CA), $47 \mathrm{~cm} \times 50 \mathrm{~mm}$ i.d., 10 $\times 800 \mu \mathrm{m}$ aperture) was performed at $40^{\circ} \mathrm{C}$ with a voltage of $26 \mathrm{kV}$ and a current of $48 \mu \mathrm{A}$. The polarity for $\mathrm{CE}$ was set with the positive pole at the capillary inlet, and the detection of samples was by UV adsorption at $208 \mathrm{~nm}$.

\section{Particle Size Distribution}

Drops of thawed ice cream were characterized for particle size distribution and specific surface area by static light scattering using a Mastersizer 2000 (Malvern Instruments, Malvern, UK) and the method of Bolliger et al. (2000). The refractive index contrast [i.e., ratio between the refractive index of fat globules (1.456) and that of the continuous phase (1.330)] was 1.095. The average fat globule size was reported as De Brouckere mean diameter $\left(\mathrm{d}_{[4,3]}=\Sigma \mathrm{n}_{\mathrm{i}} \mathrm{d}_{\mathrm{i}}^{4} / \Sigma \mathrm{n}_{\mathrm{i}} \mathrm{d}_{\mathrm{i}}^{3}\right)$ or Sauter mean diameter $\left(\mathrm{d}_{[3,2]}=\mathrm{P} \Sigma \mathrm{n}_{\mathrm{i}} \mathrm{d}_{\mathrm{i} / \Sigma \mathrm{n}_{\mathrm{i}}}^{3} \mathrm{~d}_{\mathrm{i}}^{2}\right.$, where $\mathrm{n}_{\mathrm{i}}$ is the number of fat globules with diameter $\left.d_{i}\right)$. Values for specific surface area $\left(\mathrm{m}^{2} \mathrm{~g}^{-1}\right)$ were also reported.

\section{Scanning Electron Microscopy}

Ice cream specimens (approximately $100 \mathrm{~mm}^{3}$ ) for low-temperature scanning electron microscopy were

Table 4. Proportion of individual proteins in the supernatant (as \% of total protein) after centrifugation at $40,000 \times \mathrm{g}$ for $60 \mathrm{~min}$ of reconstituted skim milk powder solutions with or without calcium chloride addition

\begin{tabular}{lcc}
\hline & \multicolumn{2}{c}{ Concentration (\% wt/wt) } \\
\cline { 2 - 3 } Protein & $\begin{array}{c}4.4 \mathrm{~g} \mathrm{~L}^{-1} \mathrm{CaCl}_{2} \\
\text { added }\end{array}$ & $\begin{array}{c}\text { No added } \\
\mathrm{CaCl}_{2}\end{array}$ \\
\hline$\alpha$-Lactalbumin & $25.02^{\mathrm{a}}$ & $23.94^{\mathrm{a}}$ \\
$\beta$-Lactoglobulin & $49.22^{\mathrm{a}}$ & $47.12^{\mathrm{a}}$ \\
$\alpha_{\mathrm{s} 1}$-Casein & $7.85^{\mathrm{a}}$ & $8.26^{\mathrm{a}}$ \\
$\alpha_{\mathrm{s} 2}$-Casein & Not detectable & Not detectable \\
$\kappa$-Casein & $9.81^{\mathrm{a}}$ & $9.29^{\mathrm{a}}$ \\
$\beta$-Casein & $8.10^{\mathrm{a}}$ & $11.39^{\mathrm{b}}$ \\
\hline
\end{tabular}

${ }^{a, b}$ Values with the same letters in the same row are not significantly different $(P>0.05)$. taken from the inner bulk of the hardened samples at $-25^{\circ} \mathrm{C}$ with a surgical blade and immediately placed into liquid nitrogen $\left(-196^{\circ} \mathrm{C}\right)$. Small pieces $(2 \mathrm{~mm} \times 3$ $\mathrm{mm}$ ) for the low-temperature scanning electron microscopy specimen holders were then broken from the specimen with the surgical blade under slight force. The holders were a double screw spring-loaded support style (Caldwell et al., 1992a) each holding 2 specimens. The holder and specimens under liquid nitrogen were transferred into a cryopreparation unit (EMscope SP2000A, Ashford, Kent, UK). At $-160^{\circ} \mathrm{C}$ inside the unit, both specimens were fractured, revealing a fresh surface of the ice cream sample for scanning. The specimens were sublimated at $-80^{\circ} \mathrm{C}$ for 25 min (Caldwell et al., 1992a) and then sputter-coated with a 30-nm layer of gold at $-160^{\circ} \mathrm{C}$. The holder was transferred under vacuum into the cold stage $\left(-140^{\circ} \mathrm{C}\right)$ of the Hitachi S-570 scanning electron microscope (Tokyo, Japan), where samples were viewed and photographed at $10 \mathrm{kV}$ accelerating voltage using different magnifications. At least 3 pieces of each ice cream sample from different containers and 20 fields per piece were viewed (Bolliger et al., 2000).

\section{Transmission Electron Microscopy}

Ice cream specimens (approximately $100 \mathrm{~mm}^{3}$ ) for transmission electron microscopy were taken from the inner bulk of the hardened samples at $-25^{\circ} \mathrm{C}$ with a surgical blade and immediately placed into liquid nitrogen $\left(-196^{\circ} \mathrm{C}\right)$, where they were broken into $<1 \mathrm{~mm}^{3}$ pieces. The freeze-substitution technique was based on that of Goff et al. (1999) and Smith et al. (2004). Frozen specimens of ice cream were transferred into vials that contained 3\% (vol/vol) glutaraldehyde in absolute methanol, which had been kept at $-80^{\circ} \mathrm{C}$ for $4 \mathrm{~d}$. Samples were transferred to $-40^{\circ} \mathrm{C}$ for $1 \mathrm{~d}$, during which the fixative mixture melted, and gradual freeze substitution of ice with methanol and some fixation with glutaraldehyde took place. Samples were then transferred to $-20^{\circ} \mathrm{C}$ for $2 \mathrm{~d}$ where fixation proceeds at a faster rate. The fixative mixture was replaced by washing the specimens in precooled $\left(-20^{\circ} \mathrm{C}\right) 100 \%$ methanol followed by washing with absolute ethanol. Infiltration of specimens with resin was carried out by graded washing with a mixture of methanol and LR Gold resin at volume ratios of $3: 1,1: 1$, and 1:3, followed by washing in $100 \%$ resin. Specimens were placed into gelatin capsules filled with resin containing $0.1 \%$ (wt/vol) benzyl and held overnight. Then, the resin-infiltrated samples were polymerized under $360 \mathrm{~nm}$ of ultraviolet light at $-20^{\circ} \mathrm{C}$. Resin blocks were sectioned at a thickness of $90 \mathrm{~nm}$ using an LKB ultramicrotome (Leica Reicherd Ultracut S, Vienna, Austria). Sections were immediately mounted on nickel-coated grids (Marivac Ltd., Halifax, 
Table 5. Fat partial coalescence in ice cream as measured by fat particle size (cumulative percentage of distribution $>3 \mu \mathrm{m}$, specific surface area, volume-weighted diameter $\mathrm{d}_{[4,3]}$, surface-weighted diameter $\mathrm{d}_{[3,2]}$ ) in the presence and absence of $\kappa$-carrageenan and calcium chloride

\begin{tabular}{|c|c|c|}
\hline \multirow[b]{2}{*}{ Ice cream } & \multicolumn{2}{|c|}{ Partial coalescence $(\%)$} \\
\hline & $\begin{array}{c}\kappa \text {-Carrageenan } \\
(0.025 \%)\end{array}$ & $\begin{array}{c}\kappa \text {-Carrageenan } \\
(0 \%)\end{array}$ \\
\hline Distribution $>3 \mu \mathrm{m}\left(4.4 \mathrm{~g} \mathrm{~L}^{-1} \mathrm{CaCl}_{2}\right.$ added $)$ & $81.2^{\mathrm{a}}$ & $32.9^{\mathrm{b}}$ \\
\hline Distribution $>3 \mu \mathrm{m}\left(\right.$ no added $\left.\mathrm{CaCl}_{2}\right)$ & $28.0^{\mathrm{b}}$ & $34.4^{\mathrm{b}}$ \\
\hline Surface area $\left(4.4 \mathrm{~g} \mathrm{~L}^{-1} \mathrm{CaCl}_{2}\right.$ added $)$ & $2.23^{\mathrm{a}}$ & $17.53^{\mathrm{c}}$ \\
\hline Surface area (no added $\mathrm{CaCl}_{2}$ ) & $21.10^{\mathrm{b}}$ & $14.30^{\mathrm{d}}$ \\
\hline $\mathrm{d}_{[4,3]}\left(4.4 \mathrm{~g} \mathrm{~L}^{-1} \mathrm{CaCl}_{2}\right.$ added $)$ & $17.56^{\mathrm{a}}$ & $5.52^{\mathrm{b}}$ \\
\hline $\mathrm{d}_{[4,3]}\left(\right.$ no added $\left.\mathrm{CaCl}_{2}\right)$ & $3.75^{\mathrm{b}}$ & $4.54^{\mathrm{b}}$ \\
\hline $\mathrm{d}_{[3,2]}\left(4.4 \mathrm{~g} \mathrm{~L}^{-1} \mathrm{CaCl}_{2}\right.$ added $)$ & $2.95^{\mathrm{a}}$ & $0.38^{\mathrm{b}}$ \\
\hline $\mathrm{d}_{[3,2]}\left(\right.$ no added $\left.\mathrm{CaCl}_{2}\right)$ & $0.32^{\mathrm{b}}$ & $0.47^{\mathrm{b}}$ \\
\hline
\end{tabular}

${ }^{a-d}$ Values with the same letters within each set are not significantly different $(P>0.05)$.

Nova Scotia, Canada) and analyzed by Philips CM 10 transmission electron microscope (using image capture software; Olympus Soft Imaging System, Markham, Ontario, Canada).

\section{Dynamic Light Scattering}

To determine casein micelle size, a Malvern Dynamic Light Scattering (DLS) instrument (Malvern Instruments, Malvern, UK) with a He-Ne laser (wavelength $633 \mathrm{~nm}$ ) was used. Model solutions of MSNF and $\kappa$ carrageenan were prepared at the same weight ratio as in a typical ice cream mix: $13 \% \mathrm{MSNF}, 0.025 \% \kappa$ carrageenan, and different concentrations of calcium chloride $\left(0,20,40,60\right.$, and $\left.80 \mathrm{~m} M \mathrm{Ca}^{2+}\right)$. When the calcium concentration was varied, the model solution was adjusted to ensure the proper weight ratio was maintained. The solutions were prepared by adding the dry $\kappa$-carrageenan to reconstituted skim milk that was prepared from skim milk powder. The solutions were stirred for approximately $30 \mathrm{~min}$ at room temperature and were then held overnight at $4^{\circ} \mathrm{C}$. The following morning, the solutions were heated for $30 \mathrm{~min}$ at $63^{\circ} \mathrm{C}$. This temperature was sufficient to solubilize the $\kappa$-carrageenan in the coil form. The samples were measured in DLS at $25^{\circ} \mathrm{C}$ as dilute systems with $5 \mu \mathrm{L}$ of model solution added to $3 \mathrm{~mL}$ of buffer $(5 \mathrm{mM} \mathrm{CaCl} 2$ and 20 $\mathrm{m} M$ imidazole, $\mathrm{pH}$ 6.7; Spagnuolo et al., 2005). Each model solution was tested 3 times with the average of 10 measurements (each an average of 20 subruns) for each run. Each solution was repeated in triplicate (different solution but same composition) for a total of 9 runs per model solution.

\section{RESULTS}

\section{Freezing Properties of the Mix}

Characteristics of the total heat flow curve of ice cream mix are shown in Table 1 . The thermograms were very repeatable with different treatments. No significant differences $(P>0.05)$ in nucleation temperature on freezing or in peak melting temperature or enthalpy on melting were seen among the 4 treatments studied. The average nucleation, peak melting, and onset temperatures, and enthalpy were $-16.2^{\circ} \mathrm{C},-1.7^{\circ} \mathrm{C},-14.1^{\circ} \mathrm{C}$, and $218.8 \mathrm{~J} \mathrm{~g}^{-1}$, respectively. Hence, calcium chloride or $\kappa$-carrageenan addition had no measureable influence on freezing point depression or freeze concentration in these systems.

\section{Ice Crystal Sizes in Ice Cream}

Median circular diameters $\left(\mathrm{X}_{50}\right)$ of ice crystals in fresh and heat-shocked ice cream are shown in Table 2. In the fresh ice cream, the addition of calcium chloride led to significantly larger ice crystal sizes $(P<0.05)$ in the absence of $\kappa$-carrageenan and to an increasing trend in ice crystal size in the presence of $\kappa$-carrageenan, although insignificant $(P>0.05)$. The addition of $\kappa$ carrageenan had no significant effect $(P>0.05)$ on ice crystal size either in the absence or presence of calcium chloride. Temperature cycling significantly increased ice crystal sizes in all cases. In the temperature-cycled samples, the presence of calcium chloride led to a significantly larger $(P<0.05)$ ice crystal size in either the absence or presence of $\kappa$-carrageenan, whereas the presence of $\kappa$-carrageenan led to significantly larger ( $P$ $<0.05)$ ice crystal size, but only in the presence of calcium chloride. The samples with calcium chloride also showed a significantly higher $(P<0.05)$ rate of growth of ice but only in the presence of $\kappa$-carrageenan, although this value has to be interpreted together with the size data to be meaningful.

\section{Protein Distribution}

Reconstituted skim milk powder solutions in the presence and absence of calcium chloride were ultracen- 


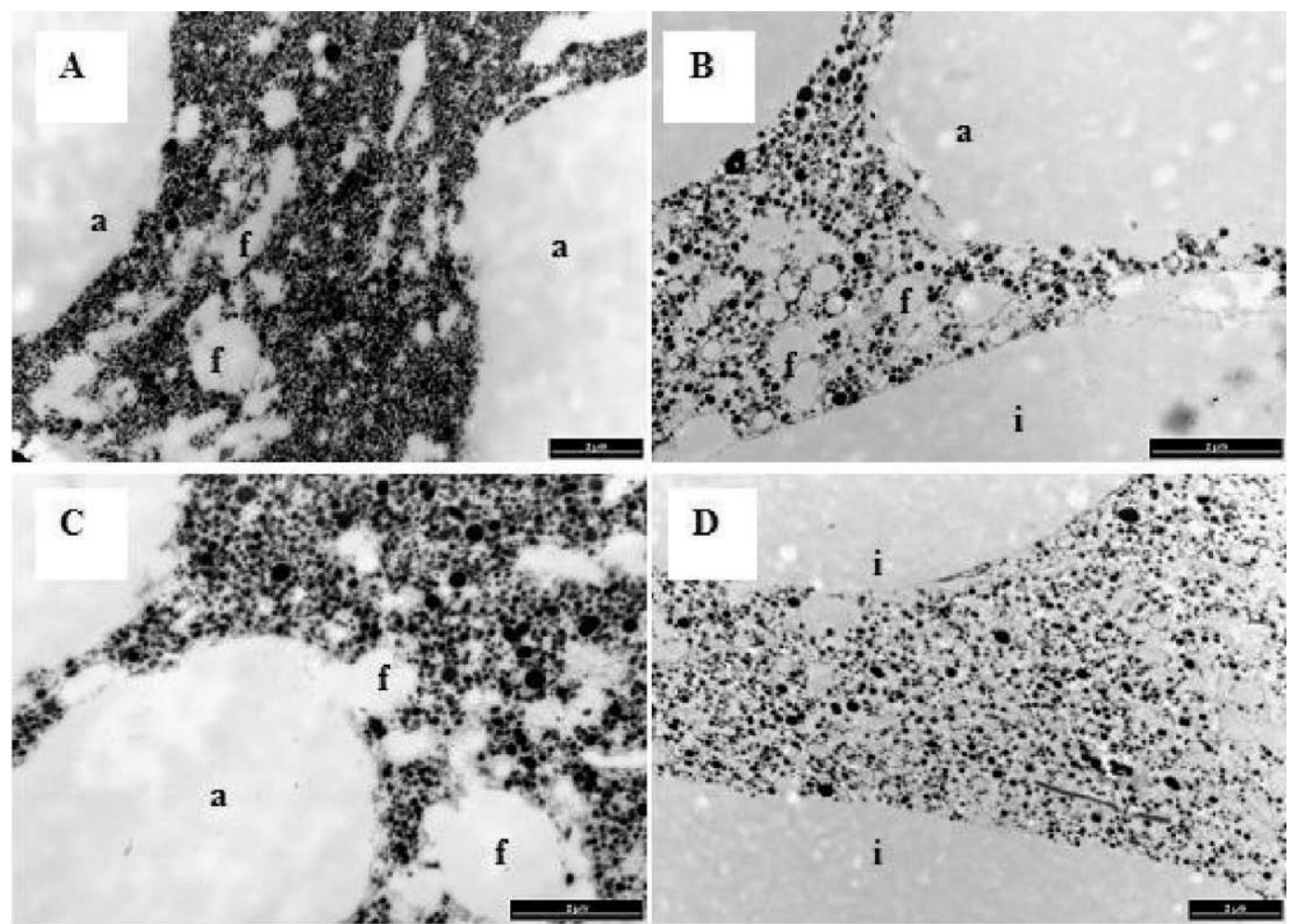

Figure 1. Transmission electron micrographs of ice cream with or without $\kappa$-carrageenan and calcium chloride (A, $\kappa$-carrageenan and calcium chloride; $\mathrm{B}, \kappa$-carrageenan only; $\mathrm{C}$, calcium chloride only; $\mathrm{D}$, without $\kappa$-carrageenan or calcium chloride). $\mathrm{Bar}=2 \mu \mathrm{m}$; a $=$ air bubble; $\mathrm{f}=$ fat globule; $\mathrm{i}=$ ice crystal.

trifuged to determine the distribution of micellar vs. nonmicellar caseins. The volume percentage of supernatant significantly increased $(P<0.05)$, and the volume percentage of precipitate significantly decreased $(P<0.05)$ after ultracentrifugation due to the addition of calcium chloride (Table 3 ). Calcium chloride addition led to significantly less $(P<0.05)$ serum $\beta$-casein. No differences were found among the other fractions (Table 4).

\section{Fat Partial Coalescence}

The addition of calcium chloride or $\kappa$-carrageenan had no effect $(P>0.05)$ on fat droplet sizes in the ice cream mixes (data not shown). Fat particle size analyses in the ice cream (Table 5) showed that calcium chloride addition in the presence of $\kappa$-carrageenan led to an excessive increase in fat emulsion destabilization $(P$ $<0.05$ ), as shown by percentage of the distribution $>$ $3 \mu \mathrm{m}$, specific surface area, $\mathrm{d}_{[4,3]}$, and $\mathrm{d}_{[3,2]}$. Although optimal partial coalescence of fat leads to structure that restricts ice recrystallization rates, fat churning would exceed this optimum. Calcium chloride addition in the absence of $\kappa$-carrageenan had no significant effect $(P>$ 0.05 ) on fat partial coalescence. Likewise, the addition of $\kappa$-carrageenan in the absence of calcium chloride had no significant effect $(P>0.05)$ on fat partial coalescence in ice cream.

\section{Ice Cream Structure}

In general, scanning electron microscopy showed that air bubbles in ice cream appeared spherical with diameters 10 to $50 \mu \mathrm{m}$ or distorted by the growth of nearby ice crystal, fat globules appeared as smaller spheres with diameters 0.2 to $1.0 \mu \mathrm{m}$ or as partially coalesced clusters, and ice crystals appeared as rectangles or polygons, with sizes depending on ingredients, processing, and storage conditions (not shown). Differences between fat globule partial coalescence or ice crystal sizes in the 4 different treatments, as seen analytically, were not discernible at this level of magnification. However, transmission electron microscopy pictures of the different treatments of ice cream (Figures 1 to 3 ) were useful to show differing levels of development of fat destabilization in the ice cream with calcium chloride added, especially in the presence of $\kappa$-carrageenan, as evident by higher adsorption of fat to the air interface, more interconnected fat globules, and coalesced fat masses with less protein adsorption to their surface (Figures 

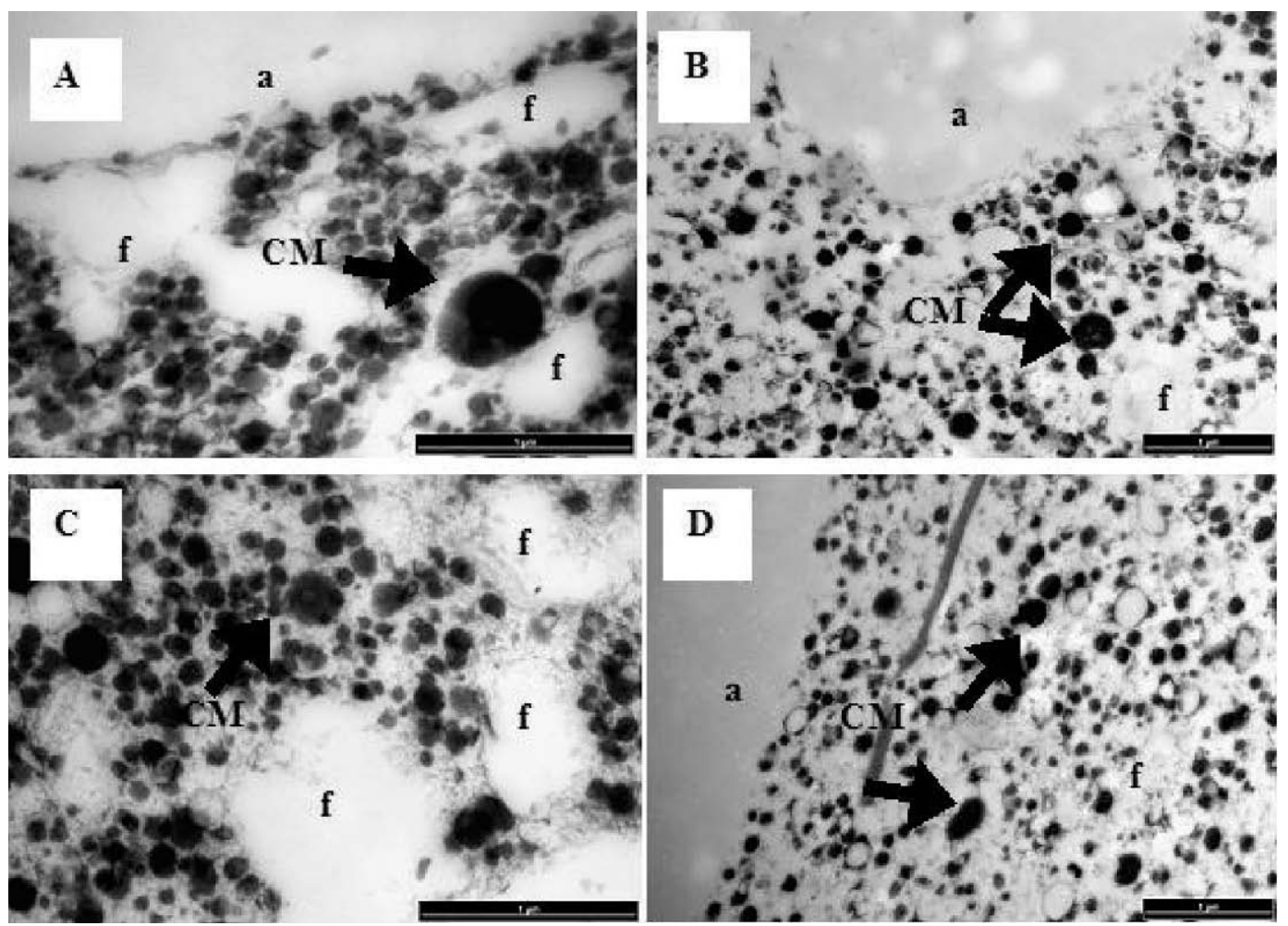

Figure 2. Transmission electron micrographs of ice cream with or without $\kappa$-carrageenan and calcium chloride (A, $\kappa$-carrageenan and calcium chloride; B, $\kappa$-carrageenan only; C, calcium chloride only; D, without $\kappa$-carrageenan or calcium chloride). Bar $=1 \mu \mathrm{m}$; a $=$ air bubble, $\mathrm{CM}=$ casein micelle; $\mathrm{f}=$ fat globule .

$1 \mathrm{~A}, 2 \mathrm{~A}$, and $3 \mathrm{~A})$. When no calcium chloride was added, both in presence and absence of $\kappa$-carrageenan to ice cream, a thicker protein layer was evident at the fatserum interface (Figures $2 \mathrm{~B}$ and $\mathrm{D}$ and $3 \mathrm{~B}$ and $\mathrm{D}$ ). This protein adsorption seemed to reduce fat-fat connections.

\section{Casein Micelle Size}

The addition of $0.015 \% \kappa$-carrageenan to a solution of $13 \%$ MSNF in the absence of added calcium led to a significant increase $(P<0.05)$ in casein micelle diameter, from 202.3 to $233.6 \mathrm{~nm}$. As the concentration of calcium chloride was increased within the range 0 to $80 \mathrm{mM} \mathrm{Ca}{ }^{2+}$ in solutions containing $\kappa$-carrageenan, there was a direct linear increase in casein micelle diameter $\left(r^{2}=0.828\right.$, Figure 4$)$. The temperature of measurement was $25^{\circ} \mathrm{C}$, well below the coil-to-helix transition temperature, indicating that $\kappa$-carrageenan was in helical conformation. This linear increase in micelle diameter might indicate further adsorption of $\kappa$-carrageenan to the surface of the micelle promoted by the presence of calcium. In the absence of $\kappa$-carrageenan, there was a decreasing trend of casein micelle size with calcium chloride addition $\left(\mathrm{r}^{2}=0.984\right)$, but the slope was considerably smaller. These results suggest that in the presence of calcium chloride and $\kappa$-carrageenan, there is competition between $\kappa$-carrageenan- $\kappa$-casein interaction and casein-casein interactions leading to surface adsorption and bridging of casein micelles, despite the effect of calcium alone on the casein micelle, which promotes association of intramicellar proteins and a decrease in micelle size.

\section{DISCUSSION}

The addition of calcium chloride to ice cream mix in the presence of $\kappa$-carrageenan had a large negative effect on ice cream structure and quality, leading to enhanced ice crystal sizes, especially after heat shock, and excessive fat destabilization. The effects of calcium addition to milk systems are well known, resulting in enhanced casein interactions (Fox and McSweeney, 1998). Modifications of the micellar-nonmicellar calcium equilibrium are used frequently to modify milk coagulation and cheese yield (Fox et al., 2000). Due to the complex distribution of calcium in milk (Little and Holt, 2004), any changes to ionic strength, ionic calcium concentration, or $\mathrm{pH}$ could result in effects on casein distribution and casein micelle stability (Tsioulpas et 

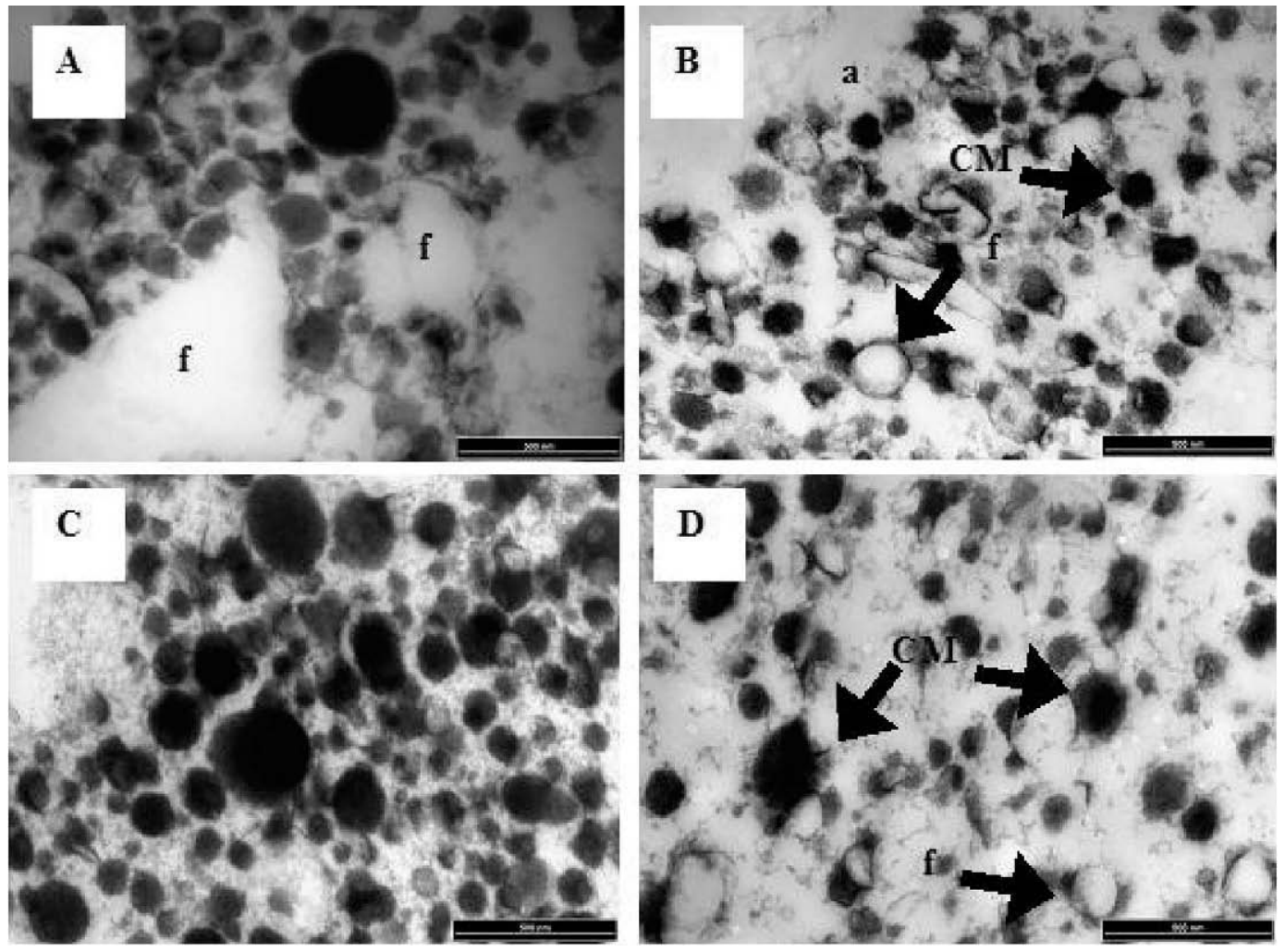

Figure 3. Transmission electron micrographs of the serum phase from ice cream with or without $\kappa$-carrageenan and calcium chloride (A, $\kappa$-carrageenan and calcium chloride; $\mathrm{B}, \kappa$-carrageenan only; $\mathrm{C}$, calcium chloride only; $\mathrm{D}$, without $\kappa$-carrageenan or calcium chloride). Bar $=500 \mathrm{~nm} ; \mathrm{a}=$ air bubble; $\mathrm{CM}=$ casein micelle; $\mathrm{f}=$ fat globule.

al., 2007). Williams et al. (2005) showed that the addition of soluble calcium chloride to reconstituted skim milk powder led to a proportional increase in free calcium, suggesting that the calcium ion was able to affect the milk salt micellar:nonmicellar equilibria. Lin et al. (2006) showed that calcium chloride addition to milk led to a linear increase in ionic calcium concentrations, reduced $\mathrm{pH}$, and less protein stability to ethanol and heat. As was shown by our results, calcium chloride addition led to a more compact micelle size by DLS, smaller pellet on centrifugation, and less serum $\beta$-casein. We attributed these effects to the ionic calcium dissociated (either completely or partially) from calcium chloride and also to the changes in the total ionic strength and $\mathrm{pH}$. These changes to protein structure would reduce the volume occupancy of casein micelles in the unfrozen phase in ice cream and would also reduce the soluble protein content of the unfrozen serum phase. Both of these would be expected to have a direct effect on ice crystallization, enhancing rates due to a reduction in both serum phase viscosity and steric hinderance (Goff, 2003). Although calcium chloride would theoretically depress the freezing point of a solution, at the concentration levels used here and in the pres- ence of a large concentration of sugars, no significant effects were seen on mix freezing properties; hence, the effect of calcium chloride on ice crystal size was for reasons other than these.

Calcium chloride addition to ice cream mix in the presence of $\kappa$-carrageenan led to a dramatic increase in fat particle size, through coalescence. This was observed in both light scattering and microscopy analyses. Casein micelles and nonmicellar $\beta$-casein can both adsorb to fat globules, leading to an enhancement of fat globule stability. However, in the presence of added calcium chloride, the more compact casein micelle structure and less serum $\beta$-casein would lead to a reduction in membrane proteins adsorbed to the fat interface. This, in turn, would lead to a lower stability of fat globules to partial coalescence during whipping and freezing of ice cream mix. This effect of calcium ions on fat destabilization in ice cream has been recognized for a long time (Marshall et al., 2003). Dauphas et al. (2008) recently showed that calcium interfered in the stabilization of oil droplets in emulsions by $\beta$-casein. Although optimal fat partial coalescence leads to a fat globule network formation that can reduce the size distribution and rate of growth of ice crystals in ice cream (Flores 


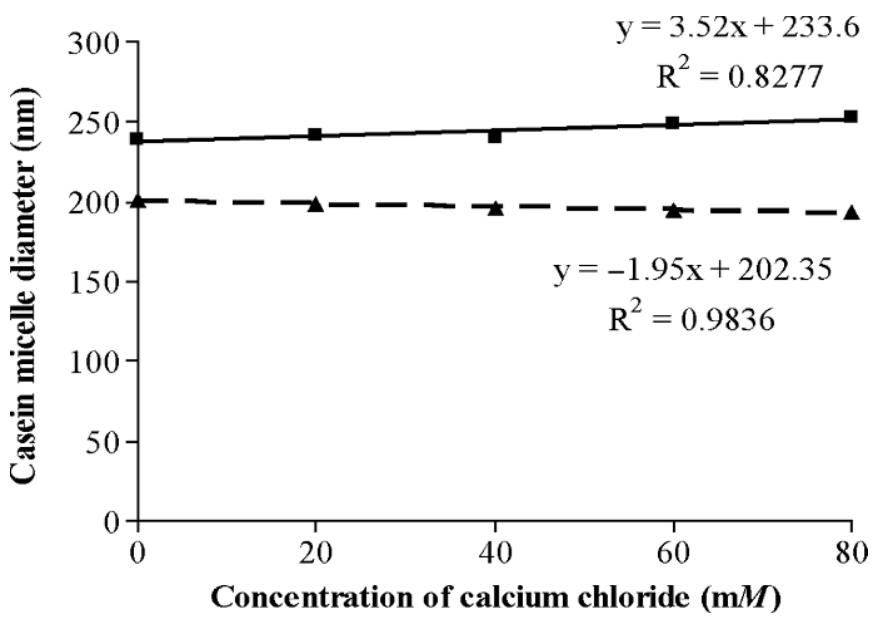

Figure 4. The effect of calcium chloride concentration on casein micelle diameter (with trendline and corresponding regression equation) in the presence $(\boldsymbol{\square})$ and absence $(\boldsymbol{\Delta})$ of $0.025 \% \kappa$-carrageenan as measured by dynamic light scattering at $25^{\circ} \mathrm{C}$.

and Goff, 1999; Barfod, 2001), excessive fat destabilization would be expected to have the opposite effect as the fat network coalesces into fat masses that are no longer capable of providing steric hinderance to growing ice crystals.

The effect of calcium chloride on ice crystal size and fat destabilization was greatly affected by the presence of $\kappa$-carrageenan, suggesting some synergistic or interacting effect, because $\kappa$-carrageenan in the absence of calcium had no significant effects on these structural parameters. Our light-scattering data suggested more $\kappa$-carrageenan adsorption to the casein micelle, or more $\kappa$-carrageenan-casein micelle aggregate formation, in the presence of calcium ions. Enhanced $\kappa$-carrageenan self-interactions would also have occurred due to the presence of the calcium ions, through $\kappa$-carrageenan sulfate ionic bridging. Interactions of $\kappa$-carrageenan and $\kappa$-casein or casein micelles have been well documented and studied (Dalgleish and Morris, 1988; Spagnuolo et al., 2005; Vega et al., 2005). This $\kappa$-carrageenan-casein micelle interaction was probably the cause of the greatly reduced fat globule stability through a reduction in fat globule surface adsorption of proteins. The reduction in serum $\beta$-casein, as described above, together with the reduction in availability of casein micelles to stabilize fat globules due to their interaction with $\kappa$-carrageenan, mediated by calcium ions, would promote the excessive fat destabilization that was seen, which in turn would allow for greater rates of ice recrystallization.

\section{CONCLUSIONS}

Calcium fortification by the addition of calcium chloride in a conventional ice cream formulation using
MSNF sources containing micellar casein led to negative effects on ice cream physical properties, structure, and quality, which were not alleviated but rather exacerbated by the presence of $\kappa$-carrageenan. The strong interrelationships that exist between structural elements in ice cream were demonstrated here: reduction in the emulsifying ability of the protein by changes in micelle structure led to reduced fat globule stability (enhanced fat destabilization), and both, in turn, led to enhanced rates of ice recrystallization. Successful calcium fortification of ice cream would therefore require additional formulation modifications. The selection of the calcium fortificant is critical. If soluble calcium salts are used, then ionic calcium may become an issue, as shown here. Formulation modification suggestions would be the inclusion of citrate or phosphate ions; EDTA or other sequestering agents, which would modify the micellar:nonmicellar calcium ratios; modified stabilizer-emulsifier blends; or incorporation of functional proteins that would stabilize the fat globule in the mix but allow for optimal fat partial coalescence in ice cream. Insoluble calcium fortificants, if they do not lead to textural issues, or calcium-protein complexes could be other alternatives.

\section{ACKNOWLEDGMENTS}

We wish to acknowledge the Natural Sciences and Engineering Research Council of Canada for financial support and Jonathan Aleong and Sandy Smith (University of Guelph) for laboratory support.

\section{REFERENCES}

Agboola, S., and D. G. Dalgleish. 1996. Kinetics of the calcium-induced instability of oil-water emulsions: Studies under quiescent and shearing conditions. LWT 29:425-432.

Antipova, A. S., E. Dickinson, B. S. Murray, and M. G. Semenova. 2002. One the effect of calcium ions on the sticking behaviour of casein-coated particles in shear flow. Colloids Surf. B Biointerfaces 27:123-131.

Augustin, M. A., and R. P. W. Williams. 2002. Technological aspects of calcium fortification of milk and dairy products. Food Aust. 54:131-133.

Barfod, N. 2001. The emulsifier effect. Dairy Ind. Int. 66:32-33.

Berry, M. J. 2007. Bioavailability of calcium from ice cream compared to milk. Proc. 3rd Int. Dairy Fed. Ice Cream Symp., Cologne, Germany. ZDS, Solingen, Germany.

Bolliger, S., H. D. Goff, and B. W. Tharp. 2000. Correlation between colloidal properties of ice cream mix and ice cream. Int. Dairy J. 10:303-309.

Caldwell, K. B., H. D. Goff, and D. W. Stanley. 1992a. A low-temperature scanning electron microscopy study of ice cream. I. Techniques and general microstructure. Food Struct. 11:1-9.

Caldwell, K. B., H. D. Goff, and D. W. Stanley. 1992b. A low-temperature scanning electron microscopy study of ice cream. II. Influence of selected ingredients and processes. Food Struct. 11:11-23.

Costa, F. F. 2006. Effect of additives on crystallization of ice cream. MS Diss. Fed. Univ. Lavras, Lavras, Minas Gerais, Brazil.

Costa, F. F., J. V. Resende, L. R. Abreu, P. H. F. Silva, R. R. Lima and F. C. R. Ribeiro. 2006. Effect of carrageenan, calcium and 
citrate on recrystallization and distribution of ice in ice cream mass. Braz. Dairy J. 61:3-9.

Dalgleish, D. G., and E. R. Morris. 1988. Interactions between carrageenans and casein micelles: Electrophoretic and hydrodynamic properties of the particles. Food Hydrocoll. 2:311-320.

Dauphas, S., M. Amestoy, G. Llamas, M. Anton, and A. Riaublanc. 2008 . Modification of the interactions between $\beta$-casein stabilized oil droplets with calcium addition and temperature changing. Food Hydrocoll. 22:231-238.

De Kruif, C. G., and C. Holt. 2003. Casein micelle structure, functions and interactions. Pages 233-276 in Advanced Dairy Chemistry. 1. Proteins. 3rd ed. P. F. Fox and P. L. H. McSweeney, ed. Kluwer Acad., New York, NY.

Flores, A. A., and H. D. Goff. 1999. Ice crystal size distributions in dynamically frozen model solutions and ice cream as affected by stabilizers. J. Dairy Sci. 82:1399-1407.

Fox, P. F., T. P. Guinee, T. M. Cogan, and P. L. H. McSweeney. 2000. Pages 128-129 and 196-200 in Fundamentals of Cheese Science. Aspen Publ., Gaithersburg, MD.

Fox, P. F., and P. L. H. McSweeney. 1998. Dairy Chemistry and Biochemistry. Thomson Sci., New York, NY.

Funami, T., M. Hiroe, S. Noda, I. Asai, S. Ikeda, and K. Nishirari. 2007. Influence of molecular structured imaged with atomic force microscopy on the rheological behavior of carrageenan aqueous systems in the presence or absence of cations. Food Hydrocoll. 21:617-629.

Goff, H. D. 1997. Colloidal aspects of ice cream. Int. Dairy J. $7: 363-373$.

Goff, H. D. 2003. Ice cream. Pages 1063-1085 in Advanced Dairy Chemistry. Vol. 1. Proteins, 3rd ed. P. F. Fox and P. L. H. McSweeney, ed. Kluwer Acad., New York, NY.

Goff, H. D., E. Verespej, and A. K. Smith. 1999. A study of fat and air structures in ice cream. Int. Dairy J. 9:817-829.

Langendorff, V., G. Cuvelier, C. Michon, B. Launay, A. Parker, and C. G. De Kruif. 2000. Effects of carrageenan type on the behaviour of carrageenan/milk mixtures. Food Hydrocoll. 14:273-280.

Lin, M.-J., M. J. Lewis, and A. S. Grandison. 2006. Measurement of ionic calcium in milk. Int. J. Dairy Technol. 59:192-199.

Little, E. M., and C. Holt. 2004. An equilibrium thermodynamic model of the sequestration of calcium phosphate by casein phosphopeptides. Eur. Biophys. J. 33:435-447.

Marshall, R. T., H. D. Goff, and R. W. Hartel. 2003. Ice Cream. 6th ed. Kluwer Acad., New York, NY.

Nickerson, M. T., A. T. Paulson, and F. R. Hallett. 2004. Dilute solution properties of $\kappa$-carrageenan polysaccharides: Effect of potassium and calcium ions on chain conformation. Carbohydr. Polym. 58:25-33.
Rees, D. A., I. W. Steele, and F. B. Williamson. 1969. Conformational analysis of polysaccharides. III. The relation between stereochemistry and properties of some polysaccharides sulfates (I). J. Polym. Sci. C 28:261-276.

Regand, A., and H. D. Goff. 2002. Effect of biopolymers on structure and ice recrystallization in dynamically frozen ice cream model systems. J. Dairy Sci. 85:2722-2732.

Regand, A., and H. D. Goff. 2006. Ice recrystallization inhibition in ice cream as affected by ice structuring proteins from winter wheat grass. J. Dairy Sci. 89:49-57.

Russell, A. B., P. E. Cheney, and S. D. Wantling. 1999. Influence of freezing conditions on ice crystallisation in ice cream. J. Food Eng. 39:179-191.

Schorsch, C., M. G. Jones, and I. T. Norton. 2000. Phase behaviour of pure micellar casein/ $\kappa$-carrageenan systems in milk salt ultrafiltrate. Food Hydrocoll. 14:347-358.

Singh, G., S. Arora, G. S. Sharma, J. S. Sindhu, V. K. Kansal, and R. B. Sangwan. 2007. Heat stability and calcium bioavailability of calcium-fortified milk. LWT 40:625-631.

Smith, A. K., H. D. Goff, and B. D. Sun. 2004. Freeze-substitution and low-temperature embedding of dairy products for transmission electron microscopy. J. Microsc. 213:63-69.

Spagnuolo, P. A., D. G. Dalgleish, H. D. Goff, and E. R. Morris. 2005. $\kappa$-Carrageenan interactions in systems containing casein micelles and polysaccharide stabilizers. Food Hydrocoll. 19:371-377.

Tsioulpas, A., M. J. Lewis, and A. S. Grandison. 2007. Effect of minerals on casein micelle stability of cow's milk. J. Dairy Res. $74: 167-173$

USDA. 2005. Continuing Survey of Food Intakes by Individuals, 2000-2002. USDA, Washington, DC.

Vega, C., D. G. Dalgleish, and H. D. Goff. 2005. Effect of $\kappa$-carrageenan addition to dairy emulsions containing sodium caseinate and locust bean. Food Hydrocoll. 19:187-195.

Vyas, H. K., and P. S. Tong. 2004. Impact of source and level of calcium fortification on the heat stability of reconstituted skim milk powder. J. Dairy Sci. 87:1177-1180.

Weaver, C. M. 1998. Calcium in food fortification strategies. Int. Dairy J. 8:443-449.

Weaver, C. M., and R. P. Heaney. 2006. Page 137 in Calcium in Human Health. Humana Press, Totawa, NJ.

Williams, R. P. W., L. D'Ath, and M. A. Augustin. 2005. Production of calcium-fortified milk powders using soluble calcium salts. Lait 85:369-381.

Zhang, Z., and H. D. Goff. 2004. Protein distribution at air interfaces in dairy foams and ice cream as affected by casein dissociation and emulsifiers. Int. Dairy J. 14:647-657. 